\title{
The Experiences of Pre-service Science Teachers in Educational Content Development Using Web 2.0 Tools
}

\author{
Gulden Gursoy \\ Adiyaman University, Turkey \\ ORCID: 0000-0002-4886-7645 \\ Derya Orhan Goksun \\ Adiyaman University, Turkey \\ ORCID: 0000-0003-0194-0451
}

\begin{abstract}
The present study aimed to improve the experiences of pre-service science teachers in content development using Web 2.0 tools and to determine the effects of these experiences on their self-efficacy beliefs in content development via Web 2.0 tools. The present study was conducted with a mixed design that included empirical and phenomenological methods. Forty-two pre-service science teachers participated in the study. During the implementation, pre-service teachers developed content using Web 2.0 tools such as Kahoot, Quizizz, Powtoon, Emaze, MindMeister and Toondoo and shared the content with the class using Edmodo. "Self-Efficacy Belief Scale on Fast Content Development via Web 2.0" was used as pre- and post-tests. Findings demonstrated that pre-service teachers' self-efficacy beliefs and all sub-dimensions of content development via Web 2.0 tools improved as a result of the implementation. The views of them were grouped under seven themes; prejudice, satisfaction, awareness, fun, infrastructure problems, language problems and tool problems. Additionally, when the mean of item responses were examined, it was seen that the highest one was about preparing worksheet self-efficacy belief. Furthermore, it was determined that pre-service teachers were happy to participate in the implementation, recognized ways to integrate technology in their fields, and had fun while developing content.
\end{abstract}

Keywords: Educational technologies; Web 2.0 tools; Self-efficacy; Content development; Teacher education

\section{Introduction}

Globalization facilitated the reflection of developments to large masses. Rapid adoption of technological developments in daily life was due to this fact. The adoption of technologies in everyday life led to the expectations for technology use in educational activities by learners, and these expectations were addressed in 21st century learning skills (Partnership21, 2015). Thus, it is clear that technology integration is a must in the 21st century education system.

Technology integration, in the most general sense, benefits from the current technological resources in educational-instructional processes based on certain plans to achieve active learning (Gunuc, 2017). As indicated in the definition, the process of technology integration in 
education requires a specific planning process. Educational technology use can be defined as the adoption of technology in educational activities. Planning activities such as definition of learning objectives and pedagogical approaches, analysis of learner attributes, organization of the teaching environment, and improvement of professional competencies of teachers could make the process of technology integration more complicated when compared to simple technology use. However, technology integration and technology use are similar with respect to teachers' professional competence requirements in technology. In both cases, teachers are expected to conduct instructional activities by blending the learning content with technological skills. Thus, technological pedagogical content knowledge (TPACK) model, which is one of the current models in technology integration in education, and the proposed teacher skills in the model come to the fore.

Based upon the argument that teachers are the most important components in effective technology integration, TPACK model stipulated that teachers should integrate their technology competencies with content knowledge within the framework of pedagogical approaches in organizing instructional activities (Koehler \& Mishra, 2009). This model is mainly a combination of three disciplines: technology, pedagogy, and content. Technological knowledge requires teachers to be fluent in current technological knowledge in order to use high technologies and to cope with technological advances. Pedagogical knowledge reflects the competency of the teacher in learning approaches, methods, techniques, and activities, knowledge of the teacher on learner attributes and her/his skills to organize activities accordingly. The content knowledge requires the teacher to possess the knowledge on the subject field in order to allow the learners to acquire learning achievements and to reach the next stage. Furthermore, based on the assumption that these three disciplines naturally interact with each other, the interactions between technology-pedagogy, content-pedagogy and technology-content constitute the model infrastructure. In other words, although TPACK could be perceived as simple, it becomes complicated at various points similar to every technological integration model. However, a holistic approach to TPACK would demonstrate that it emphasizes professional competence, skills and development of teachers. However, it could be easily observed that the model focuses on technology and education, which are among the most important requirements in the 21st century.

There are several studies in the literature, which reported that educational technology use had a positive impact on learning, improved academic achievements and learner satisfaction (Dochy \& Segers, 2018; Domingo \& Gargante, 2016; Jonassen, Peck, \& Wilson, 1999; Ozerbas \& Can, 2018). However, it should be noted that the technology use might have negative effects on learning as well (Wood et al., 2012). The common emphasis in the above-mentioned studies was on the technological skills that teachers utilize as organizers of teaching activities during the planning and implementation of the process and the requirement to keep these skills current. Thus, ensuring the use of planned and goal-oriented technologies is important. Professional development activities are one method to keep oneself up to date in teaching profession, in other words, to be current in rapidly advancing technologies. Another method peruses the experiences in instructional technologies acquired in teacher training institutions. Through active participation of pre-service teachers in these experiences, they could conduct technologybased or technology supported instructional activities in the future and these experiences could guide the teachers in the process. Technology supported activities in higher education are useful for students when designing their personal learning environments (Kompen, Edirisingha, Canaleta, Alsina, \& Monguet, 2019). This guidance could provide pre-service teachers with opportunities to correct the problems they encounter in the process. Thus, pre-service teachers could experience trial and error, reorganization and assessment processes during their training 
where guidance and peer support is available, not during the teaching process where they would be alone. The pre-service teacher, who could acquire techno-pedagogy knowledge in this process could also employ content knowledge. All these factors could lead to teacher training, where the students would be ready for technological integration processes using their technopedagogical content knowledge.

The contribution of teachers who could utilize high-level technologies in educational activities is considered important for the success of the continuing technology integration process in Turkey. It was considered that teachers, who can design technology-based instructional activities, would adapt easily to the integration process and would contribute more. Thus, it could be suggested that teachers should acquire technology use during teacher training in order to improve the success of technology integration in education. The studies on the use of technology in teacher training proposed inclusion of courses that aim to teach technology use in the curricula (Ipek \& Acuner, 2011; Usta \& Korkmaz, 2010), recommended that pre-service teachers should be trained in courses via learning by doing and conducting various tasks, (Cakir \& Yildirim, 2009; Ozmen, 2002), and claimed that pre-service teachers should use technologies in out-ofclassroom activities such as assignments, etc. (Arikan \& Altun, 2007) Furthermore, numerous studies were conducted on the self-efficacy of pre-service teachers on technology use (Erdemir, Bakirci, \& Eyduran, 2009; Ipek \& Acuner, 2011 etc.). Self-efficacy is defined by Bandura (1997) as the beliefs and attitudes of individuals towards organizing and utilizing the required skills to accomplish desired outcomes. As understood from definition, to develop technology use skills, self-efficacy beliefs are developed first. For improving TPACK skills of teachers, it is thought that content development self-efficacy belief is the most important issue. At this point, pre-service teachers, who are ones of the most important sharers of technology integration processes, it is important that they experience technology use and improve self-efficacy beliefs by this way.

Technology use and related self-efficacy perceptions of pre-service teachers could be improved with the above-mentioned applications. These studies, however, were usually designed with either quantitative or qualitative research methods, using a single instrument or device. In the present study, various tools such as Kahoot, Quizizz, Powtoon, Emaze, Mindmeister, Toondoo, and Edmodo were introduced to pre-service teachers and they were allowed to use various tools available for different instructional activities, and a mixed method was adopted to acquire detailed data and statistically significant findings. Furthermore, based on the knowledge that direct experiences have an impact on self-efficacy (Bandura, 1999), the present study aimed to determine the content development skills of pre-service teachers using Web 2.0 tools and the effect of these skills on their self-efficacy perceptions. On these issues, the study was considered to contribute to the literature. The general aim of the present study was to allow the pre-service teachers to experience content development using Web 2.0 tools and to determine the effects of content development with Web 2.0 tools on self-efficacy beliefs of the pre-service teachers. The following research questions were determined based on the above-mentioned aims.

1. What are the self-efficacy belief levels of pre-service teachers after experiencing content development using Web 2.0 tools?

2. Is there a significant difference between fast content development self-efficacy belief levels of pre-service teachers before and after experiencing content development using Web 2.0 tools?

3. Is there a significant difference between fast content development self-efficacy belief levels of pre-service teachers in preparing, presenting and evaluating dimensions before and after experiencing content development using Web 2.0 tools? 
4. What are the views of pre-service teachers about their experiences in content development using Web 2.0 tools, and how these views could be classified?

\section{Method}

The present study was conducted with a mixed design that includes quantitative and qualitative research methods. The mixed method is a research approach that utilizes the advantages of the combination of the above-mentioned research methods to better understand the research problem, instead of using only statistical trends and personal experiences. Combination (diversification) design, a mixed method type, was used in the present study. The combination design entails the combination of the findings obtained with the analysis of quantitative and qualitative data collected separately through appropriate techniques and tools (Creswell, 2017). The study flow chart is presented in Figure 1.

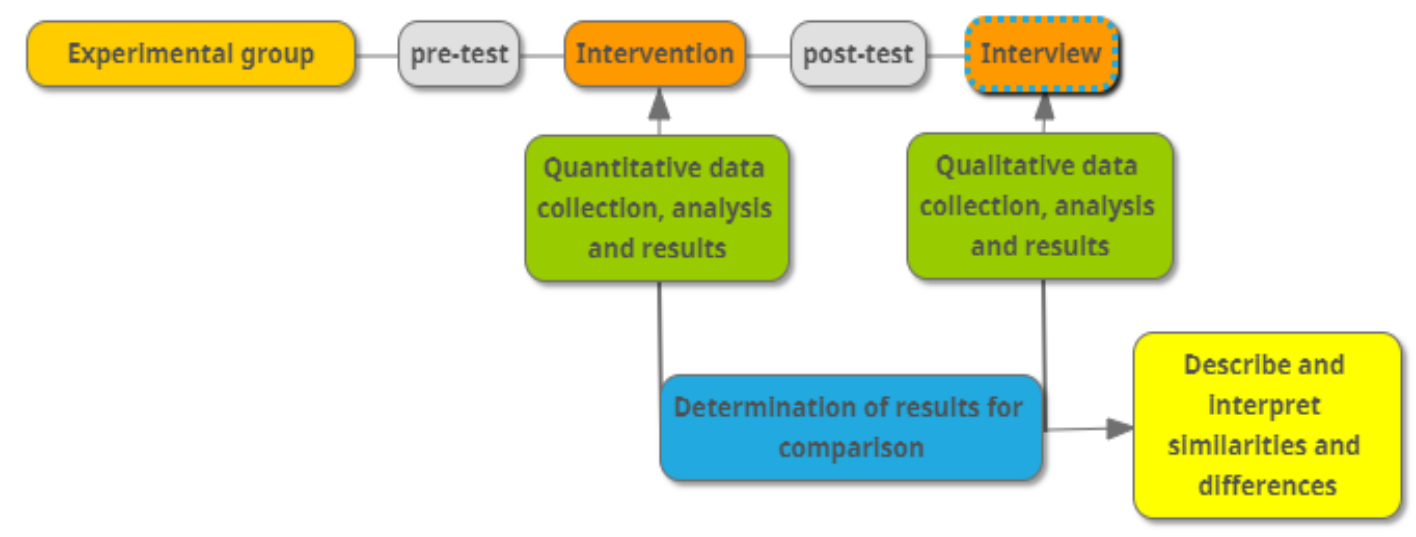

Figure 1. Mixed Method Intervention Design (Based on the Combination Design Example) Experimental Study (Creswell, 2017; 60)

Quantitative research methods were used to respond to the first three research questions. In this process, single group pre-test-post-test weak experimental design was employed and in the qualitative section of the study, phenomenological method was used. In single-group pre-testpost-test weak experimental design, the effect of the experimental procedure is tested with the same subjects and the same measurement instruments. This process was conducted in the measurement and evaluation course during the 2017-2018 academic year spring semester. During the first seven weeks of the 14-week course, the measurement and evaluation course content was instructed with technology integration in order to allow the pre-service teachers to acquire knowledge about the use of Web 2.0 tools and to observe examples. Kahoot was used to review the previous student knowledge at the beginning of the course, Quizizz was used in the evaluations conducted at the end of the course, Emaze was used for presentations, Toondoo was used to develop cartoons for the worksheets, Powtoon was used in digital storytelling, and Mindmeister was used to develop the concept map. Thus, during the measurement and evaluation course instruction assisted with Web 2.0 tools, pre-service teachers observed how Web 2.0 tools were used to instruct the course content. Furthermore, information was provided on the use of these tools, the opportunities offered by these tools and significant points. 
During the remaining six weeks of the course, content was developed by pre-service teachers using Web 2.0 tools according to the topics determined by the researcher. Five questions related to traditional assessment techniques were prepared by Kahoot and five questions related to complementary assessment techniques were prepared by Quizizz. Powtoon to prepare animations for addressing possible validity and reliability misconceptions, Emaze to prepare presentations for subject repetition, Mindmeister for mapping the concepts of measurement and evaluation course, Tondoo to create cartoon for work sheet for test and item analysis content. The flow chart that reflects the said process is presented in Figure 2.

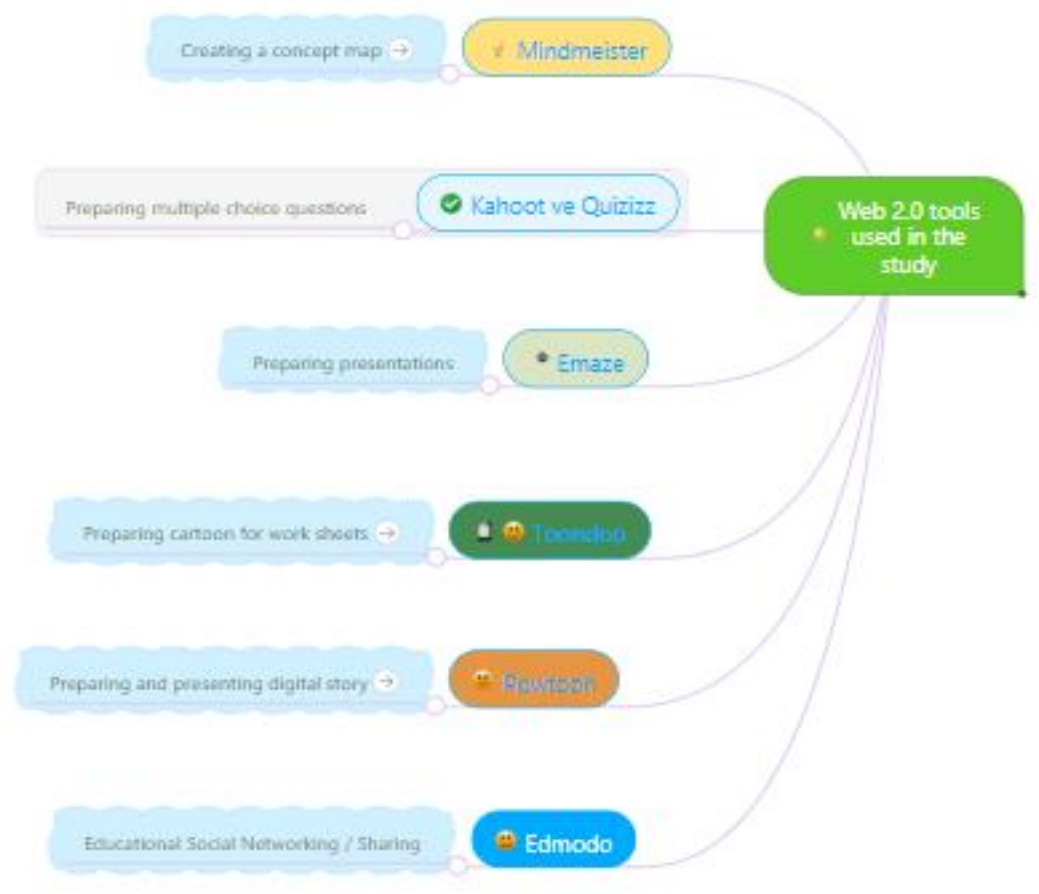

Figure 2. Web 2.0 Tools Used by Pre-service Teachers and Intended Use

As shown in Figure 2, a sample content of Web 2.0 tools that serve different purposes such as presentation, animation, measurement and evaluation questions, cartoon and concept map preparation and sharing were prepared by pre-service teacher for one week each. The scale, which was used to determine whether the content preparation process developed self-efficacy of pre-service teachers for Web 2.0 rapid content development, was applied to the pre-service teachers as pre- and post-test twice in eight weeks intervals.

In order to respond to the fourth research question, qualitative phenomenological design was used. In this design, the study is conducted with individuals or groups, who experienced, expressed or reflected the phenomenon that the researcher desired to investigate in depth and in detail (Buyukozturk, Kilic-Cakmak, Akgun, Karadeniz, \& Demirel, 2017). After the process was completed, the participants completed an interview form in which they stated their views on the advantages and limitations of the application, their satisfaction with the application and recommendations about the process and the tools they utilized. The data collected with this form was coded in themes to respond to the fourth research question. 


\section{Participants}

In the present study, purposive sampling, which is a non-random sampling method, was used. Both quantitative and qualitative data were collected with the same participants. The preservice teachers, who were computer-literate, attended the measurement and evaluation course and volunteered to participate in the study were included in the sample. The study area was selected as Adiyaman University's Faculty of Education for ease of access. Forty-two preservice science teachers $(n=42)$ were included in the study. The participant count and gender distribution of the students who participated in the quantitative and qualitative sections in the study are detailed in Table 1.

Table 1. Participants of the Qualitative and Quantitative Study Sections

\begin{tabular}{lll}
\hline Group & Gender & $\mathrm{n}$ \\
\hline Experiment & Female & 30 \\
& Male & 12 \\
Total & & 42 \\
\hline
\end{tabular}

\section{Instruments}

In the study, Web 2.0 Fast Content Development Self-Efficacy Belief (WFCDSEB) Scale and a semi-structured interview form were used as data collection instruments.

\section{Web 2.0 Fast Content Development Self-Efficacy Belief (WFCDSEB) Scale}

In order to determine the Web 2.0 tool self-efficacy levels of pre-service teachers, the WFCDSEB scale validated by Birisci, Kul, Aksu, Akaslan, and Celik (2018) was applied as a pre-test before the implementation and as a post-test after the implementation. The five-point Likert-type scale, which consists of the preparing, presenting and evaluating sub-dimensions, includes all positive coded 21 items. The overall reliability of the scale was determined as $\alpha=.955$. The data are analyzed based on the mean scale score. Birisci et al., (2018) reported that if the self-efficacy belief of individuals on the use of Web 2.0 tools is below 2.6, then the self-efficacy of these individuals is considered low, self-efficacy is considered medium when the score is between 2.63.4 and high when it is greater than 3.4. The approval to use the scale was obtained from the authors via e-mail. The reliability of the scale was determined as $\alpha=.917$ for the pre-test and $\alpha$ $=.880$ for post-test in the present study. Since the study sample was similar to the sample group on which the scale was developed, confirmatory factor analysis was not conducted.

\section{Semi-Structured Interview Form}

Immediately after the implementation, semi-structured interviews were conducted to determine the views of pre-service teachers on Web 2.0-based applications. Semi-structured interview questions were developed by the authors to assess the views of the pre-service teachers on the instructional activities. Two probe questions were determined to be used when the participants were not able to comprehend the questions. The draft interview form was reviewed by an education specialist. In particular, the expert was asked to evaluate the questions based on the aim of the study and their compliance with scientific ethical values, 
taking into account the fluency criteria. The draft form was reviewed based on the evaluation feedback and the interview form was finalized.

\section{Data Analysis}

To respond the first research question, mean analysis, a descriptive statistics method, was used. In order to determine whether the pre-service teacher WFCDSEB scale pre-test and post-test scores were distributed normally, the skewness and kurtosis coefficients were calculated. When the skewness and kurtosis coefficients are between -1.96 and +1.96 , the data distribution is considered normal (Sokal \& Rohlf, 1995). It was found that skewness and kurtosis coefficients were within this range. In order to determine whether there was a significant difference between the WFCDSEB scale pre-test and post-test scores since the sample size was adequate $(n>30)$, the parametric paired samples t-test was used. The second and third research questions were answered using the paired samples t-tests, however for the third research question, the response is obtained by the division of a single test conducted with the same data; in other words, since the research question, which was answered with a single test was divided into subfactors, Bonferroni correction was used to prevent the Type 1 error (Akbulut, 2010). Bonferroni correction was calculated by dividing the significance level by the number of tests and it was calculated as $0.05 / 3=0.017$ for the third research question and analysis results were interpreted based on this significance level.

The qualitative data obtained with the interviews that were conducted to determine the views of pre-service teachers on Web 2.0 applications were analyzed using the coding technique developed by Strauss and Corbin (1990) based on the inductive approach. In this coding technique, the coding process begins with the conceptualization of the data. Then the events and phenomena are compared based on the responses and similar events are conceptualized under same headings. The data collected on Web 2.0-based rapid content development process from the pre-service teachers were transcribed. The concepts that were determined by merging similar phenomena were identified as themes. Themes were supported by direct quotes in the findings section.

\section{Reliability and Validity}

According to Grant and Davis (1997), there should be a minimum of two weeks between the pretest and posttest measurements. In order to control the time between the pretest and posttest implementations in the study and to prevent the participants to remember their previous responses, the time between the pretest and posttest was determined as six weeks. Thus, it was considered that the general and external validity of the study, and thus, generalizability of the research was improved. In order to ensure the internal validity of the study, the questions included in the interview form were examined by an education specialist. Furthermore, the scope and the conceptual framework of the questions were determined with a literature review. The scale items were individually reviewed based on the aim of the study and assessed by the authors. In order to improve the validity of the study, the application process was explained in detail. A flowchart on the utilized Web 2.0 tools is provided. Furthermore, the method used to determine the study group, the validity and reliability of the data collection instruments, data analysis and interpretation of the data are explained in detail. 
To improve the study reliability, the measurement reliability of the data obtained with the scale was calculated for pre- and post-tests. Furthermore, two authors independently analyzed the data collected with the interviews and created the codes. The agreement between the coders was examined by an instructional technologies expert. The required editing was conducted after the expert feedback. In order to keep the identity of the participants' privacy, the participants are presented using codenames. These codenames were assigned as Pxy, where xy was the last two digits of the student number for supervision purposes. Furthermore, the participant products, interview content, the raw scale data were archived.

\section{Findings}

This section includes quantitative and qualitative findings obtained with the data collection instruments. The descriptive data, which helped to decide whether parametric or nonparametric tests should be used, are included.

Table 2. Descriptive Data on WFCDSEB Scale Pretest and Posttest Scores

\begin{tabular}{llllll}
\hline Tests & $\mathrm{n}$ & $\mathrm{M}$ & $\mathrm{SD}$ & Skewness & Kurtosis \\
\hline Pretest & 42 & 2.66 & 2.47 & .15 & .67 \\
Posttest & 42 & 4.37 & 2.79 & -.492 & -.69 \\
\hline
\end{tabular}

Based on the descriptive data presented in Table 2, it was assumed that the data distribution was normal since the scale skewness and kurtosis coefficients were between -1.96 and +1.96 . Furthermore, the mean posttest score was greater than $3.4(\mathrm{M}=4.37)$ based on the interval reported by Birisci et al. (2018). Thus, it could be stated that the WFCDSEB scores of the participant pre-service teachers were high as per the first research question.

\section{Findings on the Changes in WFCDSEB Scores}

In order to determine whether the difference between the mean pre-test score $(M=2.66)$ and mean post-test score $(M=4.37)$ of pre-service teachers was significant, the paired samples t-test was conducted. The test findings are presented in Table 3.

Table 3. Paired Samples t-test Results on the Comparison of Mean Pretest and Posttest WFCDSEB scores

\begin{tabular}{llllll}
\hline Tests & $\mathrm{n}$ & $\mathrm{M}$ & $\mathrm{SD}$ & $\mathrm{t}$ & $\mathrm{p}$ \\
\hline Pretest & 42 & 2.66 & .70 & -13.33 & .000 \\
Posttest & 42 & 4.37 & .37 & & \\
\hline
\end{tabular}

As presented in Table 3, it was determined that there was a significant difference between the WFCDSEB pre-test scores $(M=2.66)$ and post-test scores $(M=4.37)$ of pre-service teachers $(t=-$ $13.33 ; \mathrm{p}<.05)$. It was observed that this difference favored the posttest scores ( $\left.\underline{x}_{\text {posttest }}>\underline{x}_{\text {pretest }}\right)$. Thus, it was found that the mean WFCDSEB score of pre-service teachers increased after the implementation and it was considered important to determine which WFCDSEB sub-dimension, preparing, presenting or evaluating, did the pre-service teachers exhibited more improvement. Thus, the paired samples t-test was re-conducted for each scale sub-dimension. 
Table 4. Comparison of Pretest and Posttest Scores for Each WFCDSEB Scale Sub-dimension

\begin{tabular}{|c|c|c|c|c|c|c|}
\hline Subdimensions & Tests & $\mathrm{n}$ & $\mathrm{M}$ & SD & $\mathrm{t}$ & $p$ \\
\hline \multirow[t]{2}{*}{ Preparing } & Pretest & 42 & 2.56 & .82 & -12.58 & .000 \\
\hline & Posttest & 42 & 4.35 & .39 & & \\
\hline \multirow[t]{2}{*}{ Presenting } & Pretest & 42 & 3.36 & .73 & -6.57 & .000 \\
\hline & Posttest & 42 & 4.35 & .50 & & \\
\hline \multirow[t]{2}{*}{ Evaluating } & Pretest & 42 & 2.42 & .87 & -12.68 & .000 \\
\hline & Posttest & 42 & 4.45 & .42 & & \\
\hline
\end{tabular}

Since three tests were conducted for the three sub-dimensions in order to obtain the abovementioned findings, the significance level was determined as $0.05 / 3=0.017$ using the Bonferroni correction. It was found that the difference between each sub-dimension pre-test and the post-test scores was significant $\left(t_{\text {preparing }}=-12.58 ; p<.017 ; t_{\text {presenting }}=-6.7 ; p<.017\right.$; $\left.t_{\text {evaluating }}=-12.68 ; p<.017\right]$. Table 4 demonstrates that there was a significant difference between all WFCDSEB self-efficacy beliefs scale sub-dimensions. While content preparing self-efficacy beliefs were the lowest before the application, it was observed that the content preparing selfefficacy beliefs of pre-service teachers improved the most in the post-test ( $\Delta \bar{X}_{\text {preparingpretest-posttest }}$ $=-1.79 ; \Delta \bar{X}_{\text {presentingpretestpostest }}=-0.99 ; \Delta \bar{X}_{\text {evaluatingpretestposttest }}=-2.01$ ).

\section{The Views of Pre-Service Teachers on Web 2.0 Tools}

The present section is on the study findings related to the analysis of the data collected with the semi-structured interview form that included six questions and completed by the participants. Pre-service teachers were asked questions on the functions of the utilized tools, the facilities provided by these tools, their limitations, and the difficulties and opportunities they experienced during the content development process. Their views were grouped under seven themes. These themes are presented in Figure 3.

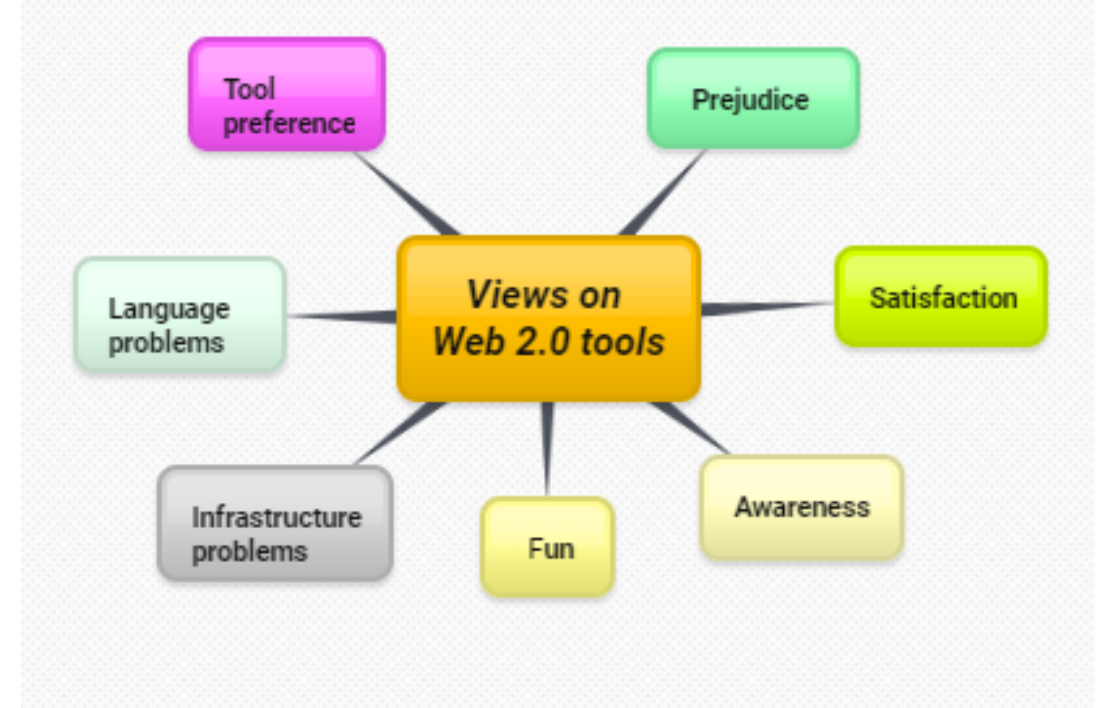

Figure 3. The Themes Determined by the Participant Views on Content Development Using Web 2.0 Tools

As seen in Figure 3, the views of the pre-service teachers were grouped under the themes of Prejudice, Satisfaction, Awareness, Fun, Infrastructure problems, Language problems and Tool Preference. 
Under the theme of prejudice, several pre-service teachers stated that they were afraid of the Web 2.0 tools and thought that they could not develop content using Web 2.0 tools. P25 stated the following: "Actually, I was scared at first and I was very confused. I told them I could not do it; but as I worked harder, I started to get a hold of it, and it was even fun to do it." Pre-service teacher P19: "The introduction was a little bit difficult. I approached with a prejudice that it would be difficult to get used to these tools. At first, development was not easy, but every time I tried I got used to it and started to see its contribution."

Under the theme of satisfaction, almost all pre-service teachers stated that they were very pleased to be introduced to Web 2.0 applications, they were more motivated for the course, the tools improved their participation in the classroom and their interest in Web 2.0 tools increased and they were happy with that. On the theme, pre-service teacher P15 stated the following: "We learned new applications and programs outside the classical programs. These programs are more fun, entertaining, and can be used to improve students' interest in and attitudes towards the course." The pre-service teacher P42 stated the following: "I never knew these applications before. It was good that our teacher introduced us. If they are actively used with the students, they would make the course more permanent utilizing the visuals."

Under the awareness theme, pre-service teachers stated that they realized educational technology use with Web 2.0 applications, their incompetence in technology use, the fact that they could not ignore technological advances, and they could learn about the technologies more easily with educational technology use. The pre-service teacher P42 stated the following: "Actually, I considered technology as a useful concept which did not lead to any real gains before, but I realized that it could be beneficial in various fields when I got to know the Web 2.0 tools." The pre-service teacher P23 stated the following: "I realized my technology use competence level. It was really awful. When I was introduced to Web 2.0 applications, I got in touch with technology and the courses seemed fluent and very nice to me."

Under the theme of fun, pre-service teachers stated that they would prefer to use these applications in their professional activities in the future since they had fun using the Web 2.0 applications that were developed by the author and their future students could have fun with them as well. They also stated that they believed that the students would be more interested in learning since these applications would make the course content fun. On the theme, the preservice teacher P16 stated the following: "I will be a teacher in the future. I can increase the retention of learning by entertaining the students. I would not only use them, but also teach my students how to use these applications." The pre-service teacher P22 stated the following: "I had great fun in the course. I think my students will have fun like I did. My students would develop positive attitudes towards the course, and they may like the course even more."

Under the theme of infrastructure problems, pre-service teachers stated that they experienced problems in procuring the necessary hardware to develop content using Web 2.0 tools. Furthermore, the pre-service teachers stated that the Internet speed was quite slow in their dormitories due to extensive use during evening hours and they had to start over when developing content due to frequent disconnections. They stated that certain applications did not accept their passwords and they experienced difficulties in saving and printing the products after development. The problems pre-service teachers experienced included the following: in Kahoot application, the character limit created problems when entering the questions, it was difficult to change the text size in Emaze, and printing the developed products was confusing in Toondoo tool. The pre-service teacher P15 stated the following: "The number of words that 
could be used was limited in some applications. It was very hard for us to deal with this limitation. Correcting these was a waste of time. We tried so hard to print out the Toondoo projects. It was very difficult to add a picture." The pre-service teacher P33 stated the following: "Since I do not own a computer, I had to borrow a computer from my friend to develop content. They were not creative, because I had to complete them in a limited period of time."

Under the theme of language problems, all pre-service teachers stated that they experienced difficulties in Web 2.0 applications development since these were available only in English. They stated that they tried to find the functions they needed by trial and error since they could not understand the button labels in application interfaces, which took a lot of time. They also emphasized that the language problem led to content creativity and originality problems. The pre-service teacher P28 stated the following: "I had several difficulties in understanding and using it because I do not speak English. And I know I was not alone. I learned the options by trialand-error, but I found that very useful." The pre-service teacher P37 stated the following: "The fact that Web 2.0 tools were in English forced me to solve the applications. During translation, the fact that Turkish and English alphabets do not match made it more difficult."

Under the tool preference theme, pre-service teachers stated that they liked to use the Powtoon application the most, followed by Edmodo and Quizizz among the utilized Web 2.0 tools. On the tool preference theme, pre-service teacher P41 stated the following: "I find Powtoon to be most useful in education. Because, we can develop musical, visual and mobile entertainment activities using simple animations. We can touch more than one sense of the students." The pre-service teacher P15 stated the following: "I found Powtoon more entertaining and positive in education. The development process was great, the implementation was fun. I think that it could attract the attention of the students and increase retention in learning." The pre-service teacher P5 stated the following: "I considered Edmodo very useful in education. It was very useful in maintaining the communication with the students and to share the course content." The pre-service teacher P30 stated the following: "Quizizz was very beneficial in measuring how much the students listened to and comprehended the instructed material."

\section{Distribution of Pre-service Teachers Based on WFCDSEB Items}

At the end of the course, the mean responses of pre-service teachers to the items in WFCDSEB scale dimensions of preparing, presenting and evaluating were analyzed. Based on the fact that each scale item measured a different skill, it was considered that the analysis would determine the skill where the self-efficacy beliefs of the pre-service teachers was the highest. The mean responses of pre-service teachers to the WFCDSEB scale are presented in Table 5.

Table 5. Mean Participant Responses to the Items in Preparing Sub-dimension

\begin{tabular}{ll}
\hline PREPARING & $\mathrm{M}$ \\
\hline I can develop worksheets using Web 2.0 tools & 4.67 \\
I can utilize Web 2.0 tools to support the course achievements. & 4.55 \\
I can create images/photographs via Web 2.0 tools. & 4.14 \\
I create educational cartoons via Web 2.0 tools. & 4.60 \\
I can guide the students in using Web 2.0 tools. & 4.36 \\
I can produce videos via Web 2.0 tools. & 4.10 \\
I can use course content material developed via Web 2.0 tools. & 4.45 \\
I can use Web 2.0 tools that are adequate for pedagogical principles and rules. & 4.17 \\
\hline
\end{tabular}




\begin{tabular}{ll}
\hline I can utilize current Web 2.0 tools. & 4.36 \\
I can produce interactive presentations via Web 2.0 tools. & 4.48 \\
I can create concept maps via Web 2.0 tools. & 4.52 \\
I can create animations via Web 2.0 tools. & 3.81 \\
\hline
\end{tabular}

As seen in Table 5, the highest mean self-efficacy belief was observed in developing worksheets with Web 2.0 applications among the pre-service teachers $(M=4.67)$. Since the pre-service teachers considered that they could develop richer worksheets using the cartoons, concept maps, puzzles and narrative techniques that they learned during the study, the self-efficacy beliefs of pre-service teachers on worksheet development could have been improved. This was an expected study outcome. The worksheets are common material used by science teachers. Any Web 2.0 tool that would improve worksheet development should be an important tool for pre-service teachers. It was determined that the self-efficacy belief levels of the pre-service teachers in creating animations using Web 2.0 tools were the lowest $(M=3.81)$. Although they stated that Powtoon tool, which they utilized to develop animations, was their favorite Web 2.0 tool, they were not confident in using it. This may be due to the complexity and comprehensive structure of the animation software interfaces and their unfamiliarity with these types of software during their previous training. The presenting sub-dimension was also analyzed in the present study. The items in presenting sub-dimension aimed to determine the skills of preservice teachers to share the material or content they developed with others. The mean frequency of the responses to the items in presenting sub-dimension are shown in Table 6.

Table 6. Mean Participant Responses to the Items in Presenting Sub-dimension

\begin{tabular}{ll}
\hline PRESENTING & M \\
\hline I can share pictures via Web 2.0 tools. & 4.38 \\
I can share videos via Web 2.0 tools. & 4.43 \\
I can share blog posts via Web 2.0 tools. & 3.98 \\
I can share presentations via Web 2.0 tools. & 4.62 \\
\hline
\end{tabular}

As seen in Table 6, although the highest Web 2.0 tool presentation development self-efficacy level of pre-service teachers were observed in the topic of "sharing the presentations," they generally considered themselves competent in the whole presenting sub-dimension. This demonstrated that pre-service teachers, who used social media actively, could transfer their daily life competencies to the presenting of the educational content they developed. The fact that self-efficacy perceptions on blogging were lower than the other fields could be due to the fact that the more specific nature of blogging. The items in the evaluating sub-dimension aimed to measure self-efficacy beliefs on the development of material that could be used in the evaluation activities. The mean responses to these items are presented in Table 7.

Table 7. Mean Participant Responses to the Items in Evaluating Sub-dimension

\begin{tabular}{ll}
\hline EVALUATING & $\mathrm{M}$ \\
\hline I can develop puzzles via Web 2.0 tools. & 4.33 \\
I can develop interactive evaluation questions via Web 2.0 tools. & 4.38 \\
I can utilize various measurement and evaluation tools using Web 2.0 tools. & 4.48 \\
I can develop tests (multiple choice, fill in the blanks, correct/incorrect, etc.) via & 4.64 \\
Web 2.0 tools. & \\
\hline
\end{tabular}


As seen in Table 7, the mean response score in this sub-dimension was over 4.00. It was observed that Web 2.0 tool evaluating content development self-efficacy belief levels of pre-service teachers were much higher when compared to preparing and presenting dimensions. In particular, the fact that they perceived themselves as very competent in the development of measurement and evaluation content, which they encountered frequently during their training, demonstrated that they did not adopt traditional measurement and evaluation techniques in content development. In other words, it could be suggested that the self-efficacy beliefs of the pre-service teachers could easily diversify the evaluation activities in their professional lives.

When table 5,6 and 7 considering holistically, it was seen that the averages of the items related to the scale are considered, even the lowest average item $(M=3.81)$ is higher than mid-point according to the rating criteria determined by Birisci et al., (2018). From this point of view, all moderators of content development self-efficacy beliefs were determined as could be supported via experiences on Web 2.0 tools' use which used for implementation. Additionally even the highest average is 4.67 , the difference is only 0.86 . This can be proved that all moderators of content development self-efficacy beliefs were improved approximately equal.

\section{Discussion and Conclusions}

In the present study, which aimed to allow the pre-service teachers to experience content development using Web 2.0 tools and to determine the impact of these experiences on their Web 2.0 tool content development self-efficacy belief levels, the data were collected separately using qualitative and quantitative methods and interpreted using comparisons. In the study, the majority of pre-service teachers stated that this was the first time they were introduced to Web 2.0 tools demonstrated by the authors in the measurement and evaluation course. The preservice teachers observed how the course could be enhanced with Web 2.0 tools during the study and observed the content development processes. The qualitative data analysis findings demonstrated that pre-service teachers were "prejudiced" against the use of these tools and considered that they could not develop course content using these tools. The WFCDSEB level of the participants was determined as moderate $(M=2.66)$ based on the scale developed by Birisci et al. (2018) before the implementation. However, as evidenced by the themes derived from the qualitative data, it could be suggested that the participants considered content development as "fun," they were "satisfied" with the introduction of Web 2.0 tools, their awareness about the necessity of the integration of technology in education and the technology itself improved, which in turn motivated the pre-service teachers for content development and increased their interest in Web 2.0 tools. The WFCDSEB levels improved due to these factors. After the implementation, the WFCDSEB level of pre-service teachers was determined as high $(M=4.37)$ based on the scale developed by Birisci et al. (2018). In order to determine whether the increase was significant, paired samples t-test was conducted and it was calculated that there was a significant difference favoring the posttest scores.

Self-efficacy is a reliable predictor of behavioral change (Lumpe \& Chambers, 2001). According to Bandura (1982), individuals with high self-efficacy could perform tasks beyond their skills, while those with low self-efficacy could not rely on their skills to cope with difficult tasks and could not complete these tasks. Although high self-efficacy beliefs of teachers on a topic do not mean that their competences would be directly reflected in their performances, studies demonstrated that high self-efficacy affects the adoption of various actions (Evers, Brouwers, \& Tomic, 2002). Teachers with high or strong sense of self-efficacy tend to be more willing and 
more involved in integration of new instruction applications (Evers et al., 2002; Knoblauch \& Hoy, 2008). Pan and Franklin (2011) reported that self-efficacy and professional development of teachers affected the use of Web 2.0 tools. A strong positive correlation between self-efficacy beliefs and the use of Web 2.0 tools in the classroom was demonstrated in a study conducted by Ward (2015). The increase in self-efficacy beliefs of pre-service teachers on content development with Web 2.0 tools indicated that they tend to make efforts to learn technological advances for the future and to integrate these tools in instructional practices. Web 2.0 tools have the ability to prepare and provide the students with all properties of a modern 21st century classroom (O'Bannon and Britt, 2012). The training of pre-service teachers to acquire high Web 2.0 tool self-efficacy perceptions would support the acquisition of 21st century skills by future students (Tu, Blocher, \& Roberts, 2006). Teachers should adapt Web 2.0 tools to the educational environment to make it easier for students to develop 21st century skills.

To facilitate the future integration of the Web 2.0 tools by teachers in their classrooms using their skills and knowledge, a well-designed professional development plan should be developed in workshops, seminars and courses in various time periods to meet the individual requirements of teachers. For pre-service teachers, workshops similar to the present study should be developed. Buchem and Hamelmann (2011) and Gray et al. (2012) proposed a requirement for practical training in instruction of Web 2.0 tools in higher education. However, technology should be introduced accurately in the program, and instructors should introduce students to the use of Web 2.0 tools and prove the benefits of these tools. Furthermore, the instructors should select the adequate tools for the course content and target audience. It should be kept in mind that preference of an inadequate tool would reduce the achievement quality (Grosseck, 2009).

The fact that pre-service teachers were satisfied with the Web 2.0 tools that they utilized to develop content and considered these tools "fun" would contribute to the development of positive attitudes towards technology integration in education. Ertmer, Ottenbreit-Leftwich, Sadik, Sendurur, \& Sendurur (2012) reported that endogenous factors (e.g., attitudes towards technology, problem-solving approach) play a key role in defining the teacher behavior. Furthermore, their awareness on the significance of Web 2.0 tools would provide clues about adopting technologies in their professional activities. Tatli, Ipek-Akbulut and Altinisik (2016) emphasized that Web 2.0 tool awareness of pre-service teachers and their adoption in professional activities were very important. It can be suggested that the present study findings demonstrated that pre-service teachers became aware of the advantages of these tools mentioned in the literature.

In order to determine whether there was a significant difference between the mean pretest and posttest scores in three scale sub-dimensions, namely preparing, presenting and evaluating subdimensions, paired samples t-test was conducted and the findings demonstrated that there were significant differences between the pretest and posttest scores in all dimensions favoring posttest scores and the highest difference was observed in the evaluating sub-dimension. This could be due to the use of Kahoot and Quizizz applications, which have gamification properties, during the tests conducted at the beginning and end of the course. The fact that pre-service teachers had fun in this process may have increased their motivation in the implementations. The most important benefit of gamification is motivation (Trentin \& Repetto, 2013). In addition to increasing the study loyalty in the classroom via motivation, gamification provides students the opportunity to receive instant feedback in the classroom (Kapp, 2012) and allow them to monitor and evaluate their achievements in the learning process. Via feedback, it improves the 
visibility of the teacher and allows students to assess their skills and to adopt to new methods (Lee \& Hammer, 2011).

Pre-service teachers considered their self-efficacy in worksheet development with Web 2.0 tools in the preparing sub-dimension the highest, and their self-efficacy in animation development as the lowest. It could be suggested that pre-service teachers may have felt more competent in worksheet development since they realized that they could improve the worksheets with Web 2.0 tools. The worksheet is one of the materials used actively during instruction. Previous studies demonstrated that the improvement of the worksheets with technology increased instructional quality (Heermann, 1988), student achievements, student interest in the course, and led to a more enjoyable course (Saka \& Yilmaz, 2005). Although pre-service teachers stated that their favorite Web 2.0 tool was Powtoon, which was used as an animation development tool, selfefficacy beliefs on animation development were lower when compared to other dimensions. This may be due to the fact that the animation development software was fun, however they wanted to know more about originality and technologies. Rioseco, Paukner, and Ramirez (2017) reached similar conclusions in a study on student views about the Powtoon tool. In the study, it was found that Powtoon allowed utilization of new skills, it was motivating, but not easy to work with. An action study conducted by Syafitri, Asib, and Sumardi (2018) demonstrated the impact of the Powtoon tool. In the study, it was determined that Powtoon motivated the students to learn and participate in the courses during the song and video applications. In another study, Tatlı, Ipek-Akbulut, and Altinisik (2016) reported that pre-service teachers liked Powtoon, QuizMaker, and EdrawMax applications the most, similar to the present study findings. It was considered that the present study tool preference findings were consistent with those reported in the literature.

Pre-service teachers considered their Web 2.0 tool presenting sharing dimension self-efficacy levels the highest, while they considered their blog post dimension self-efficacy levels the lowest. Since developing and sharing presentations is one of the most common activities they encounter during their education, pre-service teachers may have considered their self-efficacy levels high. However, since they never posted blog entries and the Web 2.0 tools that they used in content development were not directly related to blogging, they may have considered themselves less competent. In a study, Sendag, Erol, Sezgin, and Dulkadir (2015) found that the Web 2.0 tool blogging self-efficacy perceptions of pre-service teachers were one of the lowest self-efficacy levels determined. Furthermore, the authors emphasized that Turkish pre-service teachers did not frequently use blogs, wikis and podcasts in the study. Loving, Schroeder, Kang, Shimek, and Herbert (2007) similarly suggested that most teachers were not familiar with these tools and applications.

Pre-service teachers assessed their Web 2.0 tool test development self-efficacy (multiple choice, fill in the blanks, true-false, etc.) in evaluating sub-dimension as the highest, while they considered their puzzle development self-efficacy the lowest. The process of puzzle question development is one of the complementary measurement and evaluation techniques. The lack of familiarity with these techniques since they are seldom used in the education of pre-service teachers and the fact that these techniques require field expertise could have led to the low selfefficacy belief levels observed in the present study.

The analysis of the interview data demonstrated that the pre-service teachers frequently experienced two types of problems when developing content with Web 2.0 tools. One of these problems was the language problem and the other was infrastructure problem. Since Web 2.0 tool interfaces were in English, it was found that pre-service teachers could not use the interface 
buttons effectively when creating content, that prolonged the process of content development and they were frustrated. Pre-service teachers suggested that these tools should be adopted to Turkish. Furthermore, it was determined that they experienced problems when sharing the content with their classmates due to the inadequate and slow internet network in crowded environments. It was determined that pre-service teachers were frustrated since they had to develop the content several times due to Internet connection problems. Gomleksiz and Pullu (2018) determined the problems experienced by pre-service teachers when using the Web 2.0 tool Toondoo in detail in a study. They found that pre-service teachers experienced problems, because the Toondoo software was in English, slow, demanding and complex.

Technology is considered as an indispensable tool in the academic world. Educators agree that Web technologies have the potential to elicit developmental changes in higher education (Grosseck, 2009). Bush and Hall (2011) reported that the implementation of Web 2.0 technologies in the classroom would help students to acquire 21st century skills more easily. It is known that institutions that integrate Web 2.0 as a learning tool would improve student commitment to school, allow the students to fulfill individual learning requirements, develop students' critical thinking skills, provide an alternative learning environment for students, improve extracurricular learning and prepare students for lifelong learning (Lemke et al., 2009). The greatest responsibility in integrating Web 2.0 tools in teaching-learning environments belongs to teachers and teacher training institutions (Tavares, Chu, Ho, Chow, Siu, \& Wong, 2012). The faculty members, who conduct instructional activities with Web 2.0 tools adequate for the course content and assign responsibility to pre-service teachers in development of the course content using technologies, would contribute to the development of technological pedagogical content knowledge. However, in a study, Daher and Lazarevic (2014) reported that teaching staff did not possess adequate experience and they could not develop instructional content due to insufficient support in learning technologies. In order to ensure healthy progress of this cycle, Ranger and Land (2017) proposed that in-service training should be provided by instructional technologists to support the professional development of instructors to integrate Web 2.0 tools in classrooms. In order to determine the in-service training content accurately, the instructors should also possess technological pedagogical knowledge that would allow them to determine the educational demands for technology use in their field. Transformation of the Web 2.0 tools that are selected by the faculty members, who already attended related training courses, to pre-service teachers using the methods that were employed in the present study could improve the content development and Web 2.0 tool self-efficacy beliefs of the pre-service teachers.

In direct proportion to literature, pre-service teachers' content development self-efficacy levels were improved by providing Web 2.0 tool using experience in this study within control of an instructional technologist. In the frame of results of current study, it can be suggested that the implementation might be repeated for teacher training programs and inservice teachers' professional development activities. However, potential differences experimental context could not be revealed why this study conducted with only one group. Besides, this study is limited in the context of science pre-service teachers participated and measurement and evaluation course content. Within this framework, this study would be redesigned with more than one group in an experimental design, another field and pre-service teachers or inservice teachers. Additionally, Web 2.0 using experience could affect not only self-efficacy but lots of socio psychological status of people, such as technological pedagogical content knowledge, perfection on teaching, professional satisfaction. These variables should be measured in teacher education context. For future implementations, redesigned activities, which consist of more Web 2.0 tools, in an instructional design model for a teacher professional development program. 


\section{References}

Akbulut, Y. (2010). Sosyal bilimlerde SPSS uygulamalari. Istanbul: İdeal Kultur Yayincilik.

Arikan, Y. D. \& Altun, E. (2007). Sinif ve okuloncesi ogretmen adaylarinin cevrimici odev sitelerini kullanimina yonelik bir arastirma. Illkogretim Online, 6(3), 366-376.

Bandura, A. (1982). Self-efficacy mechanism in human agency. American Psychologist, 37, 122147.

Bandura, A. (1997). Self-efficacy: The exercise of control. New York: Freeman.

Bandura, A. (1999). Social cognitive theory of personality. In L. Pervin \& John, O. P. (Eds.), Handbook of personality: Theory and research (2. ed). New York: Guilford.

Birisci, S., Kul, U., Aksu, Z., Akaslan, D. \& Celik, S. (2018). WEB 2.0 hizli icerik gelistirme ozyeterlik inanci belirlemeye yonelik olcek (W2OYiO) gelistirme calismasi. Egitim Teknolojisi Kuram ve Uygulama, 8, 187-208. doi: 10.17943/etku.335164

Buchem, I. \& Hamelmann, H. (2011). Developing 21st century skills: Web 2.0 in higher education: A case study. E-learning papers, (24). Retrieved on 27 March 2019 from https://issuu.com/gfbertini/docs/developing_21st_century_skills_-_web_2.0_in_higher

Bush, L. \& Hall, J. (2011). Transforming teaching with technology: Using web 2.0 tools to enhance on-line communication, collaboration, and creativity. In M. Koehler \& P. Mishra (Eds.), Proceedings of Society for Information Technology \& Teacher Education International Conference 2011 (pp. 3887-3890) Chesapeake, VA: AACE.

Buyukozturk, S., Kilic Cakmak, E., Akgun, O.E., Karadeniz, S. \& Demirel, F. (2014). Bilimsel arastirma yontemleri (17. baski). Ankara: Pegem.

Cakır, R. \& Yildirim, S. (2009). What do computer teachers think about the factors affecting technology integration in schools. Ilkogretim Online, 8(3), 952-964.

Cresswell, J. W. (2017). Karma yontem arastirmalarina giris (Trans. Ed. M. Sozbilir). Ankara: Pegem Akademi.

Dochy, F. \& Segers, M. (2018). Creating impact through future learning: The high impact learning that lasts (HILL) model. London: Routledge.

Domingo, M. G. \& Gargante, A. B. (2016). Exploring the use of educational technology in primary education: Teachers' perception of mobile technology learning impacts and applications' use in the classroom. Computers in Human Behavior, 56, 21-28.

Erdemir, N., Bakirci, H. \& Eyduran, E. (2009). Ogretmen adaylarinin egitimde teknolojiyi kullanabilme ozguvenlerinin tespiti. Turk Fen Egitimi Dergisi, 6(3), 99-108.

Ertmer, P. A., Ottenbreit-Leftwich, A. T., Sadik, O., Sendurur, E. \& Sendurur, P. (2012). Teacher beliefs and technology integration practices: A critical relationship. Computers \& Education, 59(2), 423-435.

Evers, W. J. G., Brouwers, A. \& Tomic, W. (2002). Burnout and self-efficacy: A study on teachers' beliefs when implementing an innovative educational system in the Netherlands. British Journal of Educational Psychology, 72(2), 227-243. 
Gomleksiz, M. N. \& Pullu, E.K. (2018). Toondoo ile dijital hikayeler olusturmanin ogrenci basarisina ve tutumlarina etkisi, Turkish Studies International Periodical for the Languages, Literature and History of Turkish or Turkic, 12(32), 95-110.

Grant J. S. \& Davis L. L. (1997) Selection and use of content experts for instrument development. Res Nurs Health, 20, 269-274.

Gray, K., Waycott, J., Clerehan, R., Hamilton, M., Richardson, J., Sheard, J. \& Thompson, C. (2012). Worth it? Findings from a study of how academics assess students' Web 2.0 activities. Research in Learning Technology, 20(1), 1-15.

Grosseck, G. (2009). To use or not to use Web 2.0.0 in higher education? Procedia Social and Behavioral Sciences. 478-482.

Gunuc, S. (2017). Egitimde teknoloji entegrasyonunun kuramsal temelleri. Ankara: Ani.

Heermann, B. (1988). Teaching and learning with computers. San Francisco: Jossey-Bass.

Ipek, C. \& Acuner, H. (2011). Sinif ogretmeni adaylarinin bilgisayar oz-yeterlik inanclari ve egitim teknolojilerine yonelik tutumlari. Ahi Evran Universitesi Kırsehir Egitim Fakultesi Dergisi, 12(2), 23-40.

Jonassen, D. H., Peck, K. L., \& Wilson, B. G. (1999). Learning with technology: A constructivist perspective. Upper Saddle River, NJ: Merrill.

Kapp, K. M. (2012). The gamification of learning and instruction: Game-based methods and strategies for training and education. San Francisco, CA: Pfeiffer.

Knoblauch, D. \& Hoy, A. W. (2008). "Maybe I can teach those kids." the influence of contextual factors on student teachers' efficacy beliefs. Teaching \& Teacher Education, 24(1), 166179.

Koehler, M. \& Mishra, P. (2009). What is technological pedagogical content knowledge (TPACK)? Contemporary Issues in Technology and Teacher Education, 9(1), 60-70.

Kompen, R. T., Edirisingha, P., Canaleta, X., Alsina, M., \& Monguet, J. M. (2019). Personal learning Environments based on Web 2.0 services in higher education. Telematics and Informatics, 38, 194-206.

Lee, J. J. \& Hammer, J. (2011). Gamification in education: What, how, why bother? Definitions and uses. Exchange Organizational Behavior Teaching Journal, 15 (2), 1-5.

Lemke, C., Coughlin, E., Garcia, L., Reifsneider, D., \& Baas, J. (2009). Leadership for Web 2.0 in Education: Promise and reality. Culver City, CA: Metiri Group.

Loving, C. C., Schroeder, C., Kang, R., Shimek, C. \& Herbert, B. (2007). Blogs: Enhancing links in a professional learning community of science and mathematics teachers. Contemporary Issues in Technology and Teacher Education, 7(3), 178-198.

Lumpe, A. T. \& Chambers, E. (2001). Assessing teachers' context beliefs about technology use. Journal of Research on Technology in Education, 34(1), 93-107.

O'Bannon, B.W. \& Britt, V.G. (2012). Creating/developing/using a wiki study guide: Effects on student achievement. Journal of Research on Technology in Education, 44(4), 293-312.

Ozerbas, M. A. \& Can, O. (2018). Ogretim yazilimlarinin onemi ve uygulanabilirligine yonelik sinif ogretmenlerinin gorusleri. Journal of Turkish Educational Sciences, 16(1), 26-41. 
Ozmen, H. (2002). Fen bilimleri ogretmen adaylarinin teknolojik pedagojik alan bilgilerindeki ve ogretmenlik oz yeterlik inanclarindaki degisimlerin incelenmesi. The Turkish Online Journal of Educational Technology, 3(1), 100-111.

Pan, S. C. \& Franklin, T. (2011). In service teachers' self-efficacy, professional development, and Web 2.0 tools for utilization. New Horizons in Education, 59(3), 28-40.

Partnership21. (2015). P21 framework definitions. Retrieved on 27 March 2019 from http://www.p21.org/storage/documents/docs/P21_Framework_Definitions_New_Logo _2015.pdf at 30 August 2018.

Rioseco, M., Paukner, F., \& Ramirez, B. (2017). Incorporating Powtoon as a learning activity into a course on technological innovations as didactic resources for pedagogy programs. Int. J. Emerg. Technol. Learn.,12, 120-131.

Saka, A. \& Yilmaz, M., (2005). Bilgisayar destekli fizik ogretiminde calisma yapraklarina dayali materyal gelistirme ve uygulama. The Turkish Online Journal of Educational Technology, 4(3), 120-131.

Sendag, S , Erol, O , Sezgin, S. \& Dulkadir, N. (2015). Preservice teachers' critical thinking dispositions and web 2.0 competencies. Contemporary Educational Technology, 6(3), 172-187.

Sokal, R. R. \& Rohlf, F. J. (1995). Biometry: The principles and practice of statistics in biological research. New York: WH Freeman and Company

Syafitri, A., Asib,A. \& Sumardi,S. (2018). An application of Powtoon as a digital medium: Enhancing students' pronunciation in speaking. International Journal of Multicultural and Multireligious Understanding, 5(2), 295-317

Tavares, N. J., Chu, D., Ho, S. Y., Chow, K., Siu, F. L. C. \& Wong, M. (2012). Developing upper primary students' 21st century skills: Inquiry learning through collaborative teaching and Web 2.0 technology. Hong Kong: Centre for Information Technology in Education, Faculty of Education, The University of Hong Kong.

Tatli, Z., Ipek-Akbulut, H. \& Altinisik, D. (2016). Ogretmen adaylarinin teknolojik pedagojik alan bilgisi ozguvenlerine web 2.0 araclarinin etkisi. Turk Bilgisayar ve Matematik Egitimi Dergisi, 7(3), 659-678.

Trentin, G. \& Repetto, M. (2013). Using network and mobile technology to bridge formal and informal learning. Oxford, UK: Woodhead/Chandos.

Tu, C., Blocher, M. \& Roberts, G. (2008). Constructs for Web 2.0 learning environments: A theatrical metaphor. Educational Media International, 45(4), 253-269.

Usta, E. \& Korkmaz, O. (2010). Ogretmen adaylarinin bilgisayar yeterlikleri ve teknoloji kullanimina iliskin algilari ile ogretmenlik meslegine yonelik tutumlari. Uluslararasi insan Bilimleri Dergisi, 7(1), 1335-1349.

Ward, S. (2015). The impact of self-efficacy and professional development on implementation of web 2.0 tools in elementary classrooms. Education Dissertations and Projects. 140. Retrieved from https://digitalcommons.gardner-webb.edu/education_etd/140 at 20 December 2018.

Wood, E., Zivcakova, L., Gentile, P., Archer, K., De Pasquale, D. \& Nosko, A. (2012). Examining the impact of off-task multi-tasking with technology on real-time classroom learning. Computers \& Education, 58(1), 365-374. 
CONTEMPORARY EDUCATIONAL TECHNOLOGY, 2019, 10(4), 338-357

DOI: https://doi.org/10.30935/cet.000000 - TYPE: Research Article

Correspondence: Derya Orhan Goksun, Ph.D., Department of Computer Education and

Instructional Technologies, Faculty of Education, Adiyaman University, Adiyaman, Turkey 